Fourth International Conference on Sustainable Construction Materials and Technologies http://www.claisse.info/Proceedings.htm

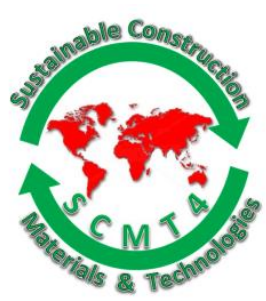

SCMT4

Las Vegas, USA, August 7-11, 2016

\title{
Using NDT Methods for Evaluating the Cementitious Material After Repair According to ACI 224 Procedure
}

\author{
Amir Mohammad Ramezanian Poor ${ }^{1}$, Mohammad Mahdi Khodavirdi Zanjani², Sara \\ Bonyadian $^{3}$, and Negin Amin Saboori ${ }^{4}$ \\ ${ }^{1}$ Assistant Professor at Tehran University. Email: 〈ramezanian@ut.ac.ir〉, \\ ${ }^{2}$ Student of M.Sc. in Structural Engineering at Tehran University and Technical manager of Construction \\ Material Laboratory of Ale-Taha University. Email:<Concrete.eng@gmail.com〉, \\ ${ }^{3}$ Student of B.Sc. in Civil engineering at Ale-Taha University \\ Email:<sara.bonyadian@gmail.com>,
}

${ }^{4}$ Student of B.Sc. in Civil engineering at Ale-Taha University; Email:<negin.aminsaboori@yahoo.com>.

\begin{abstract}
According to American Concrete Institute, formation of cracks in concrete components can have different reasons; and effects show themselves just superficially, or noticeable they decrease in durability or/and instability of components. Materials and methods of repairing cracks are of different types and have been chosen after analyzing the crack according to ACI224.1R-07 report along with issues mentioned in ACI546.3R-06 report titled as "Concrete Repair Guide". After repairing the crack in concrete, there are different ways to control quality of usable materials, but most of the approaches related to filling cracks are among destructive tests and are impossible in some cases. After surveying causes of crack formation, approaches and needed materials to repair by information have been brought in ASTM C 597 standard, and in respect to differences of pulse velocity in environment with different densities, quality of repaired mortar and comparison of it with a normal concrete in this paper will be discussed. In the trend of experiments, an internal free space has been made in a mortar, especially a internal free space has been filled with the purpose of increasing load capacity through common methods mentioned in ACI224.1R-07 (Resin Epoxy Injection, Grout Injection, Routing and Sealing). Finally through comparison of pulse velocity in controlled mortar with required concrete and results from nondestructive ultrasonic test, the filled areas of cracks have been determined through a nondestructive method.
\end{abstract}

\section{INTRODUCTION}

Cracks in concrete have many causes. They may affect appearance only, or they may indicate significant structural distress or a lack of durability. Cracks may represent the total extent of the damage, or they may point to problems of greater magnitude. Their significance depends on the type of structure, as well as the nature of the cracking. For example, cracks that are acceptable for buildings may not be acceptable in water-retaining structures. [ACI Committee 224 (2007)] The first step in development of repair for a cracked concrete structure is to determine the cause of the cracking. Cracking may be caused by internal 
and external mechanisms, such as thermal expansion, overloading, restraint, and chemical reactions. The cracks themselves range from very small, internal microcracks to very large cracks caused by external, that is, environmental factors. Cracking may occur shortly after casting while the concrete is in a plastic state or when it is in the hardened state. [Delatte (2009)] Repairing cracks through techniques made by committee 224 in American Concrete Institute and recommended materials in committee ACI 54 have different ways which can be applied based on types and analyses of cracks and then recommends the way of repair. In this project, first we focus on reasons of crack formation in different levels of making concrete and reasons for repairing them and also recording nondestructive crack tests based on UT. After reviewing techniques for repairing cracks based on ACI 224.1R-07 report and needed materials based on ACI546.3R-06 report, it tends to make $15^{*} 15^{*} 1$ mple and presents a technique for filling it. After that we compared changing the pulse velocity in normal mortar and the mortar which is repaired. Determining quality of repaired mortar causes finding different kinds of knowledge needed to know about cause of cracks and the way of repairing it. Semi destructive and non-destructive methods recommended here are based on techniques suggested by committee ACI228.

\section{TYPES OF CRACKS}

Cracks are categorized as occurring either in plastic concrete or hardened concrete. [ACI Committee 224 (2007)] Concrete can crack in any or in each of the following three phases of its life, namely:

1.1 In its plastic-phase while it has still not set (has just been placed), the concrete can crack due to plastic shrinkage, plastic settlement and differential settlement of staging 'supports'.

1.2 In its hardening-phase while it is still green (first three to four weeks), the concrete can crack due to constraint to early thermal movement, constraint to early drying shrinkage and differential settlement of 'supports'.

1.3 In its hardened-phase and in service (after first 28 days), the concrete can crack due to overload, under-design, inadequate construction, inadequate detailing, differential settlement of 'foundations', sulphate attack on cement in concrete, rusting of reinforcement (due to chloride attack on reinforcement, carbonation effect on concrete, simple oxidation of reinforcement due to exposure to moisture), 'Alkali - aggregate' reaction, fabrication, shipment and handling cracks in precast, prestressed or reinforced concrete members, crazing, weathering cracks, long term drying-shrinkage cracks. [RAINA (1994)]

\section{SELECTION OF REPAIR PRODEDURES}

Based on the careful evaluation of the extent and cause of cracking, procedures can be selected to accomplish one or more of the following objectives:

Restore or increase strength, Restore or increase stiffness, Improve functional performance, Provide water tightness, Improve appearance of the concrete surface, Improve durability, Prevent development of a corrosive environment at reinforcement.

The Summary of nondestructive testing methods are mentioned as follow: Visual inspection, Ultrasonic pulse velocity, Ultrasonic-echo, Impact-echo, Spectral analysis of surface waves, Sonic-echo, Impulseresponse, Impedance logging, Cross hole sonic logging, Parallel seismic. The ultrasonic nondestructive test was used to determine the concrete condition, the crack depth and afterwards controls. The ultrasonic machines instruction and the related tolerance are compatible with the following characteristics. [ACI Committee 224 (2007)]

\subsection{ULTRASONIC TEST (UT)}


Following items can be evaluated via nondestructive ultrasonic test:

2.1.1 Determination of Concrete Uniformity. [IAEA-TCS-17 (2002)]

3.1.2 Cracks and Voids. [UNICEMNTO. (2004)]

3.1.3 Measuring Concrete Features' Change with Time. [IAEA-TCS-17 (2002)]

3.1.4 Determination of Changes in Concrete Properties. [IAEA-TCS-17 (2002)]

3.1.5 Modulus of Elasticity Measurement [ASTM C597-97. (1997)]

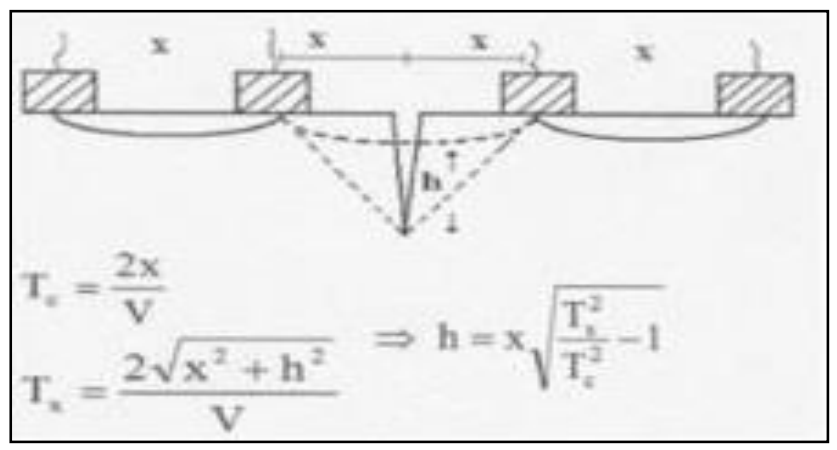

Figure 1. (a), [IAEA-TCS-17 (2002)]

$$
V=\sqrt{\frac{E(1-\mu)}{\rho(1+\mu)(1-2 \mu)}}
$$

Figure 1. (b)

$$
\mathrm{V}=\mathrm{L} / \mathrm{T}
$$

Figure 1. (c)

Figure 1. (a) Crack's Depth, (b) dynamic modulus of elasticity, and (c) Pulse velocity Calculation

(Where: $E=$ dynamic modulus of elasticity, $\mu=$ dynamic Poisson's ratio, and $\rho=$ density, $V=$ pulse velocity, $\mathrm{m} / \mathrm{s}, \mathrm{L}=$ distance between transducers, $\mathrm{m}$, and $\mathrm{T}=$ transit time, $\mathrm{s}$ )

\subsubsection{Ultrasonic Velocity Measurement [ASTM C597-97. (1997)]}

3.2 Determination of pulse velocity [IAEA-TCS-17 (2002)]

\subsubsection{Transducer Arrangement}

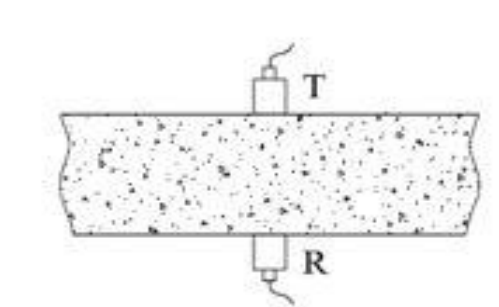

a)

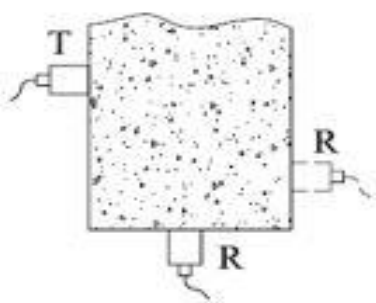

b)

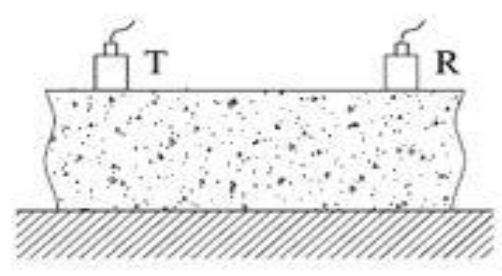

c)

Figure 2. Transducer Positioning, [UNICEMNTO. (2004)]

(Key: $\mathrm{R}$ is The Receiver transducer, $\mathrm{T}$ is The Transmitter Transducer, a) Direct transmission b) Semidirect transmission c) Indirect or surface transmission, and The Direction (a) was used for Test) 


\section{THE PROPOSAL MATERIAL IN ORDER TO REPAIR THE CRACK}

After knowing the damage and doing non-destructive experiments, determining a suitable method and choosing needed material should be in our to-do list. Regarding the wide range of usable products in crack repairing, evaluation of efficient materials will be based on the position and concrete level of the crack.

\subsection{Fine Cement Grouts}

Cement grouts are economical, readily available, easy to install, and fairly compatible with concrete. Admixtures can modify cement grouts to meet specific job requirements. Admixtures to minimize shrinkage are available on the market. Cement grouts can be used for repairs by injection only where the width of the opening is sufficient to accept the solid particles suspended in the grout. Normally, the minimum crack width at the point of introduction should be approximately $3 \mathrm{~mm}(0.1 \mathrm{in}$.). [ACI Committee 546 (2004)]

\subsection{Epoxy Grouts}

Generally, compressive strength of at least $8000 \mathrm{psi}(55 \mathrm{MPa})$ is obtained easily for most epoxy grouts. The temperature and ratio of the polymer bonding system to aggregate should be known and be the basis for setting field requirements. Qualification requirements for working time, thermal compatibility, and creep resistance for epoxy grouts are necessary and should be established because these properties vary greatly among different epoxy grouts. [ACI Committee 546 (2004)]

\subsection{Epoxy Repair Mortar (Proprietary Repair Mortars)}

The advantages of proprietary repair materials are their convenience of use in the field and the broad range of products with different physical and mechanical properties to meet the different field conditions, such as partial-depth repairs on vertical and overhead surfaces without the need of forms. Proprietary repair mortars have different mechanical properties than the concrete being repaired. Because they may be cement-rich and extended with any one or more modifiers subsequently, they can have a propensity for high shrinkage compared with conventional concrete. [ACI Committee 546 (2004)]

\subsection{Injecting Epoxy Resin}

Within hours, this same epoxy will surpass the compressive and tensile strengths of the surrounding concrete. Such effective and easily attained results make epoxy injection one of the most common ways of repairing narrow cracks. Epoxy injection alone cannot solve every crack problem. If a crack is an active crack which continues to open or close, then the cause of the crack movement must be removed or a control joint must be constructed in the area of the crack. Otherwise, the concrete will crack again nearby after the crack is injected. [MURRA (1987)]

\subsection{Cementitious Repair Mortar Modified by Latex}

Latex bonding agents are classified as Type I- Redispersible and Type II- Nonredispersible. Type II systems act as bond breakers once they have skimmed over or cured. Type I bonding agents should not be used in areas subject to water, high humidity, or structural applications. Type I bonding agents can be applied to the bonding surface several days before placing the repair materials; however, the bond strength is less than that provided by Type II bonding agents. Type II systems are best suited for bonding when mixed with cement and water to produce a slurry. These are most commonly used with PMC mixtures. [ACI Committee 503 (1993)] 


\section{THE RECOMMENDED METHODS FOR CRACK REPAIRING [ACI Committee 224 (2007)]}

After knowing the damage and evaluation for the useable materials, for repairing the crack we need to choose the crack repairing approach according to the methods mentioned in 224 American Concrete institute committee. Some of the approaches mentioned in this guide book have description in other guide books. Like Epoxy Injection in concrete which is explained in 503 American Concrete institute committee.

\subsection{Epoxy Injection}

5.1.1 Rout and seal the crack, thus treating it as a joint;

5.1.2 Establish a joint that will accommodate the movement and then inject the crack with epoxy or other suitable material;

5.1.3 Install additional support or reinforcement at the crack location to minimize movement.

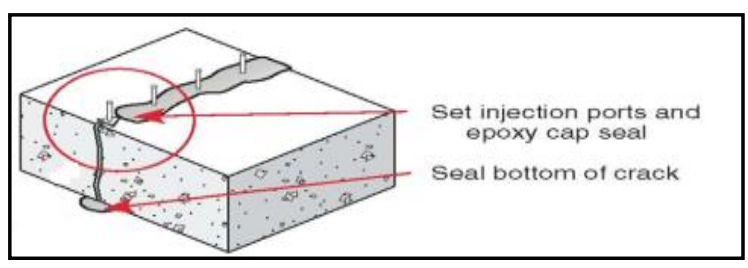

Figure 3. Epoxy Injection

\subsection{Routing and Sealing}

5.2.1 Routing and sealing of cracks can be used in conditions requiring repair where structural repair is not necessary.

5.2.2 Routing and sealing is used to treat both narrow and wide cracks.

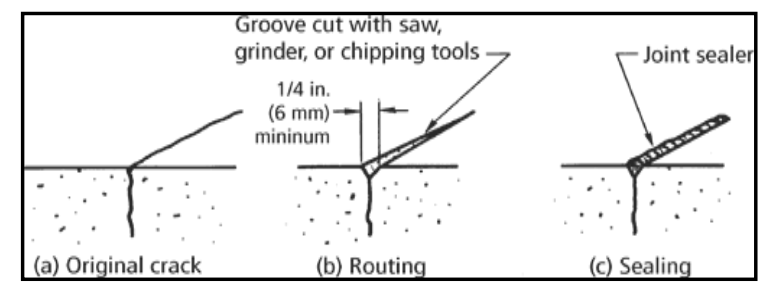

Figure 4. Routing and Sealing

\subsection{Grouting}

5.3.1 Portland-cement grouting — wide cracks, particularly in gravity dams (Warner 2004) and thick concrete walls may be repaired by filling with Portland-cement grout. This method is effective in stopping water leaks, but it will not structurally bond cracked sections.

\subsection{Gravity filling}

5.4.1 Low-viscosity monomers and resins can be used to seal cracks with surface widths of 0.001 to 0.08 in. 


\section{MAKING SAMPLES AND USED MATERIALS DESCRIPTION IN EXPERIMENTS}

According to the details given before the method for evaluation the damage of the crack and suitable materials for repairing the crack is achievable, but there isn't any method for quality control after repair except core sampling. Alternatively, quality of repaired mortar has been tried to be controlled in lab according to ultrasonic machine function. Four kinds of cubes were used during the laboratory experiment. [ACI Committee 224 (2007)]

Table 1. Material Compound

\begin{tabular}{|l|l|l|}
\hline Material & Mixing Ratio & Specific Gravity \\
\hline Epoxy Resin & $\mathrm{A}: \mathrm{B}=3: 1$ By weight or volume & $1.05 \mathrm{~kg} / 1\left(\right.$ at $\left.25^{\circ \mathrm{C}}\right)$ \\
\hline $\begin{array}{l}\text { Cementitious Repair Mortar } \\
\text { Modified by Latex }\end{array}$ & $\mathrm{A}: \mathrm{B}: \mathrm{C}=4: 10: 25$ By weight & $1.85 \mathrm{~kg} / 1\left(\right.$ at $\left.25^{\circ \mathrm{C}}\right)$ \\
\hline Epoxy Grout & $\mathrm{A}: \mathrm{B}: \mathrm{C}=3: 1: 16$ By weight & $2.1 \mathrm{~kg} / 1\left(\right.$ at $\left.25^{\circ \mathrm{C}}\right)$ \\
\hline Epoxy Mortar & $\mathrm{A}: \mathrm{B}=3: 1$ By weight or volume & $1.75 \mathrm{~kg} / 1\left(\right.$ at $\left.25^{\circ \mathrm{C}}\right)$ \\
\hline
\end{tabular}

Table 2. Mortar Mix

\begin{tabular}{|l|l|l|l|}
\hline Mortar Sample & Mixing Ratio & Specific Gravity & Compressive Strength according to TDS \\
\hline Fine & & & After 24 hours: $16 \mathrm{MPa}$ \\
Cementitious & $\begin{array}{l}7.5 \text { to } 8.5 \text { liters for } \\
\text { Grout }\end{array}$ & $\begin{array}{l}1.7 \mathrm{~kg} / \mathrm{l} \\
(\text { each } 25 \mathrm{~kg} \text { sack }\end{array}$ & After 3 days: $28 \mathrm{MPa}$ \\
& & After 7 days: 40 MPa \\
& & After 28 days: $48 \mathrm{MPa}$ \\
\hline
\end{tabular}

The first kind is an ordinary cube $(\mathrm{O})$ with the following dimensions: $150 \times 150 \times 150 \mathrm{~mm} 3$. As other cubs with an artificial crack were installed in them using a steel plate with the following dimensions: $150 \mathrm{~mm}$ height, $150 \mathrm{~mm}$ width and different thicknesses: $1 \mathrm{~mm}$ (D1) thickness, $3 \mathrm{~mm}$ (D2) thickness, and $5 \mathrm{~mm}$ (D3) thickness. Samples were made by cube forms; therefore, conversion coefficient of cube compressive strength to cylindrical compressive strength was used in all calculations.

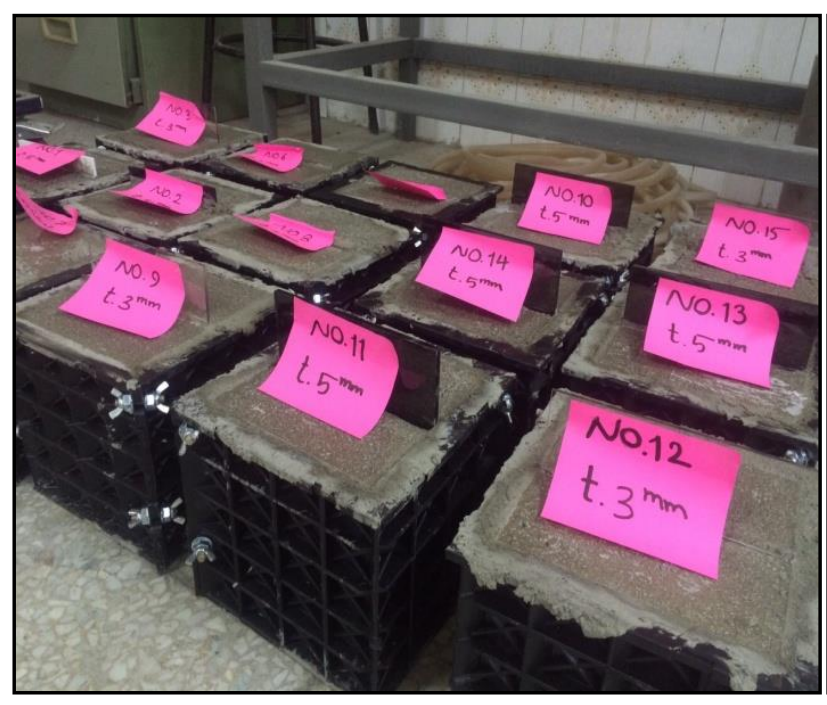

Figure 5 (a)

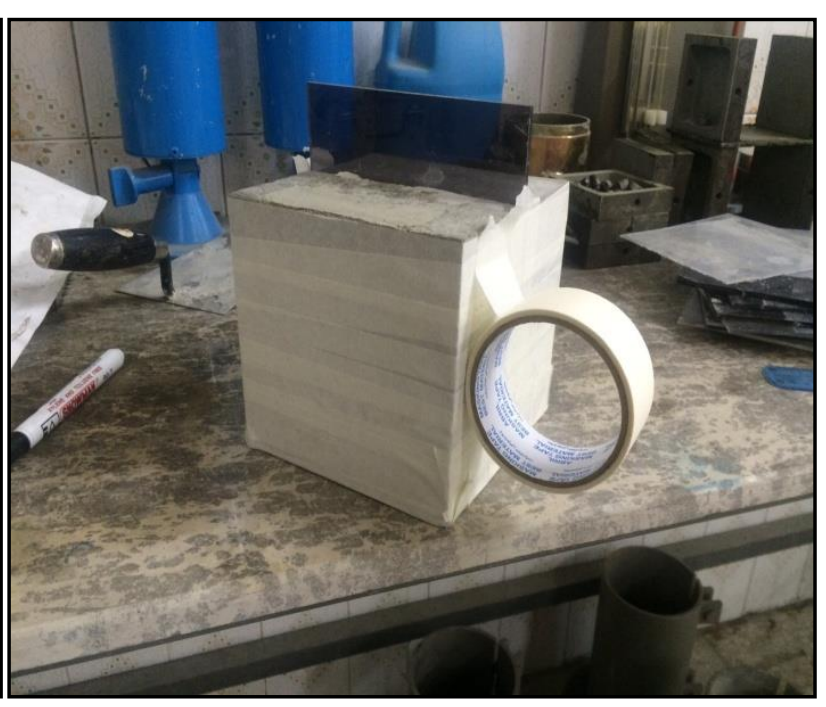

Figure $5(b)$

Figure 5 (a), (b) Cementitious Grout Specimen that has two same separate parts 
According to information given about choosing approach and repair materials, mechanical properties of repair material used to fill the gaps have been presented in table 3.

\section{Table 3. Material Compound}

\begin{tabular}{|l|l|l|l|}
\hline Mechanical Properties of Repair Materials \\
\hline Repair Material & Compressive Strength & Flexural Strength & Tensile Bond Strength \\
\hline Injecting Epoxy Resin (MPa) & 55.1 & 35 & 5.2 \\
\hline Epoxy Grouts (MPa) & 90.1 & 25 & 2.5 \\
\hline Epoxy Repair Mortar (MPa) & 65.1 & 20 & 2.5 \\
\hline $\begin{array}{l}\text { Cementitious Repair Mortar } \\
\text { Modified by Latex (MPa) }\end{array}$ & 40 & 9 & 2 \\
\hline Fine Cement Grouts (MPa) & 54 & - & - \\
\hline
\end{tabular}

\section{INSTRUCTION}

After creating needed samples, the gaps have been filled. All the cracks or gaps were made in one single direction, thus, the position of UT machine sender or receiver has been determined. Since the cracks are wall-to-wall, the machine can't send waves to depth of the crack before repairing and filling the gaps. Recording the ultrasonic wave's passage time through the repaired part in the straightway and comparing that with the uncracked part determines the range of time or wave's speed after repairing changes. Therefore the needed time in both straight and non-straight state in normal and repaired mortar will be studied.

Table 5. UT Initial Calculations, $(X=$ Width of gap, $Y=$ Time Factor $)$

\begin{tabular}{|c|c|c|c|c|c|c|}
\hline \multicolumn{7}{|l|}{ Injecting Epoxy Resin } \\
\hline \multirow{3}{*}{ Description } & \multirow{3}{*}{$\begin{array}{l}\mathrm{T}, \text { Normal } \\
\text { Mortar }\end{array}$} & \multirow{3}{*}{$\begin{array}{l}\mathrm{T} \text {, Repair } \\
\text { Material }\end{array}$} & \multirow{2}{*}{\multicolumn{3}{|c|}{$\begin{array}{l}\text { T, Repaired Mortar } \\
\text { Width of Gap - mm }\end{array}$}} & \multirow{3}{*}{ Formula } \\
\hline & & & & & & \\
\hline & & & 1.00 & 3.00 & 5.00 & \\
\hline Density & $2,200.00$ & $1,050.00$ & - & - & - & \multirow{5}{*}{$y=0.079 x+0.913$} \\
\hline $\begin{array}{l}\mathrm{L}=\text { Distance Between } \\
\text { Transducers }(\mathrm{Cm})\end{array}$ & 15.00 & 15.00 & 15.00 & 15.00 & 15.00 & \\
\hline $\begin{array}{l}\mathrm{T}=\text { Transit Time In } \\
\text { Repaired Mortar } \\
(\mathrm{s} \times 10-6)\end{array}$ & 48.17 & 100.92 & 48.45 & 54.10 & 63.70 & \\
\hline $\mathrm{V}=$ Pulse Velocity $(\mathrm{m} / \mathrm{s})$ & $3,114.19$ & $1,486.32$ & $3,095.98$ & $2,772.64$ & $2,354.79$ & \\
\hline $\begin{array}{l}\mathrm{T}=\text { Transit Time only } \\
\text { for Normal Mortar In } \\
\text { Repaired Mortar } \\
(\mathrm{s} \times 10-6)\end{array}$ & - & - & 47.85 & 47.20 & 46.56 & \\
\hline $\begin{array}{l}\mathrm{T}=\text { Transit Time only } \\
\text { for Repair Material In } \\
\text { Repaired Mortar } \\
(\mathrm{s} \times 10-6)\end{array}$ & - & - & 0.60 & 6.90 & 17.14 & \multirow{3}{*}{$\mathrm{R}^{2}=0.985$} \\
\hline $\begin{array}{l}\text { Increase or Decrease of } \\
\text { Transit Time in } \\
\text { Compare of Normal } \\
\text { Mortar }\left(s \times 10^{-6)}\right.\end{array}$ & - & - & 0.59 & 12.32 & 32.25 & \\
\hline Time Factor & - & - & 1.006 & 1.123 & 1.322 & \\
\hline
\end{tabular}


According to calculations, a parameter was introduced in which this time factor gives a time needed for pulses to go through repaired concrete with certain repair materials and certain width after passing through the sound concrete.

\section{"Transit time for Normal mortar $\times$ Time Factor $=$ Transit time in repaired mortar"}

Table 6. Calculation of the Formula for Time Factor

( $\mathrm{X}=$ Width of gap, $\mathrm{Y}=$ Time Factor, $\mathrm{L}=15 \mathrm{~cm}$ distance between transducers)

\begin{tabular}{|c|c|c|c|c|c|c|}
\hline \multicolumn{7}{|c|}{$\mathrm{T}=$ Transit Time, (In Normal an Repaired Mortar) } \\
\hline \multirow{3}{*}{ Repair Material } & \multirow{3}{*}{$\begin{array}{l}\mathrm{T}, \text { Normal } \\
\text { Mortar }\end{array}$} & \multirow{3}{*}{$\begin{array}{l}\mathrm{T} \text {, Repair } \\
\text { Material }\end{array}$} & \multirow{2}{*}{\multicolumn{3}{|c|}{\begin{tabular}{|l}
$\mathrm{T}$, Repaired Mortar \\
Width of Gap - mm
\end{tabular}}} & \multirow{3}{*}{ Formula } \\
\hline & & & & & & \\
\hline & & & 1.00 & 3.00 & 5.00 & \\
\hline Injecting Epoxy Resin (s × $10-6)$ & 48.17 & 100.92 & 48.45 & 54.10 & 63.70 & $\begin{array}{l}\mathrm{y}=0.079 \mathrm{x}+ \\
0.913\end{array}$ \\
\hline Epoxy Grouts $(\mathrm{s} \times 10-6)$ & 48.17 & 55.48 & 50.05 & 51.25 & 53.10 & $\begin{array}{l}\mathrm{y}=0.015 \mathrm{x}+ \\
1.021\end{array}$ \\
\hline Epoxy Repair Mortar $(\mathrm{s} \times 10-6)$ & 48.17 & 64.22 & 50.85 & 52.05 & 56.10 & $\begin{array}{l}\mathrm{y}=0.027 \mathrm{x}+ \\
1.018\end{array}$ \\
\hline $\begin{array}{l}\text { Cementitious Repair Mortar } \\
\text { Modified by Latex }(s \times 10-6)\end{array}$ & 48.17 & 50.80 & - & 50.60 & 53.40 & $\begin{array}{l}y=0.029 x+ \\
0.963\end{array}$ \\
\hline Fine Cement Grouts $(s \times 10-6)$ & 48.17 & 48.17 & - & - & 56.95 & - \\
\hline
\end{tabular}

Initial calculations for all kinds of repair material in this research were low the same as table 5; and calculation of the formula between time factor and changes in the crack's width in different repair materials has been shown in table 6 .

Table 7. An Analysis of The Change in Time Factor According to The Change in Materials Density and the Crack's Width or Empty Space

\begin{tabular}{|c|c|c|c|c|}
\hline $\begin{array}{l}\text { Width } \\
\text { of Gap }\end{array}$ & Repair Material & $\begin{array}{l}\text { Density } \\
\text { ( } \mathrm{Kg} / \mathrm{m} 3)\end{array}$ & $\begin{array}{l}\text { Time } \\
\text { Factor }\end{array}$ & Formula \\
\hline \multirow{5}{*}{$1 \mathrm{~mm}$} & Injecting Epoxy Resin & 1,050 & 1.0059 & \multirow{5}{*}{$y=0.643 x^{0.06}$} \\
\hline & Epoxy Grouts & 1,910 & 1.0391 & \\
\hline & Epoxy Repair Mortar & 1,590 & 1.0557 & \\
\hline & $\begin{array}{l}\text { Cementitious Repair Mortar } \\
\text { Modified by Latex }\end{array}$ & 2,010 & - & \\
\hline & Fine Cement Grouts & 2,120 & - & \\
\hline \multirow{5}{*}{$3 \mathrm{~mm}$} & Injecting Epoxy Resin & 1,050 & 1.1232 & \multirow{5}{*}{$y=2.218 x^{-0.09}$} \\
\hline & Epoxy Grouts & 1,910 & 1.0640 & \\
\hline & Epoxy Repair Mortar & 1,590 & 1.0806 & \\
\hline & $\begin{array}{l}\text { Cementitious Repair Mortar } \\
\text { Modified by Latex }\end{array}$ & 2,010 & 1.0505 & \\
\hline & Fine Cement Grouts & 2,120 & - & \\
\hline \multirow{5}{*}{$5 \mathrm{~mm}$} & Injecting Epoxy Resin & 1,050 & 1.3225 & \multirow{5}{*}{$y=6.067 x^{-0.22}$} \\
\hline & Epoxy Grouts & 1,910 & 1.1024 & \\
\hline & Epoxy Repair Mortar & 1,590 & 1.1647 & \\
\hline & $\begin{array}{l}\text { Cementitious Repair Mortar } \\
\text { Modified by Latex }\end{array}$ & 2,010 & 1.1087 & \\
\hline & Fine Cement Grouts & 2,120 & 1.1824 & \\
\hline
\end{tabular}


Table 8. Various Time Factors for Various Repaired Materials and Gaps

\begin{tabular}{|l|l|l|l|}
\hline \multirow{2}{*}{ Time Factor } & \multicolumn{3}{l|}{ Gap Width - mm } \\
\cline { 2 - 4 } Repair Material & 1.00 & 3.00 & 5.00 \\
\hline Injecting Epoxy Resin & 1.006 & 1.123 & 1.322 \\
\hline Epoxy Grouts & 1.039 & 1.064 & 1.102 \\
\hline Epoxy Repair Mortar & 1.056 & 1.081 & 1.165 \\
\hline Cementitious Repair Mortar Modified by Latex & - & 1.051 & 1.109 \\
\hline Fine Cement Grouts & - & - & 1.182 \\
\hline
\end{tabular}

\section{CONCLUSION}

- Changes in materials' kind in gaps or mortar cracks cause changes in passage of pulses through them. This change in speed can be used as an approach to control the filling. The more the depth and width of the crack, the more the time of wave's passage to the crack's depth and width. This time has a direct relation with depth and width of the crack.

- The recorded time for wave passing through normal mortar compared with cracked mortar defines a specified range. This time range is an area which needs to be studied after repair.

- Waves' speed in normal mortar is different from that of repaired concrete. This has a direct relation with repairing materials' density and concrete's quality. So, waves' speed in the repaired part, consist of concrete and repairing materials, is different from waves' speed in a normal mortar.

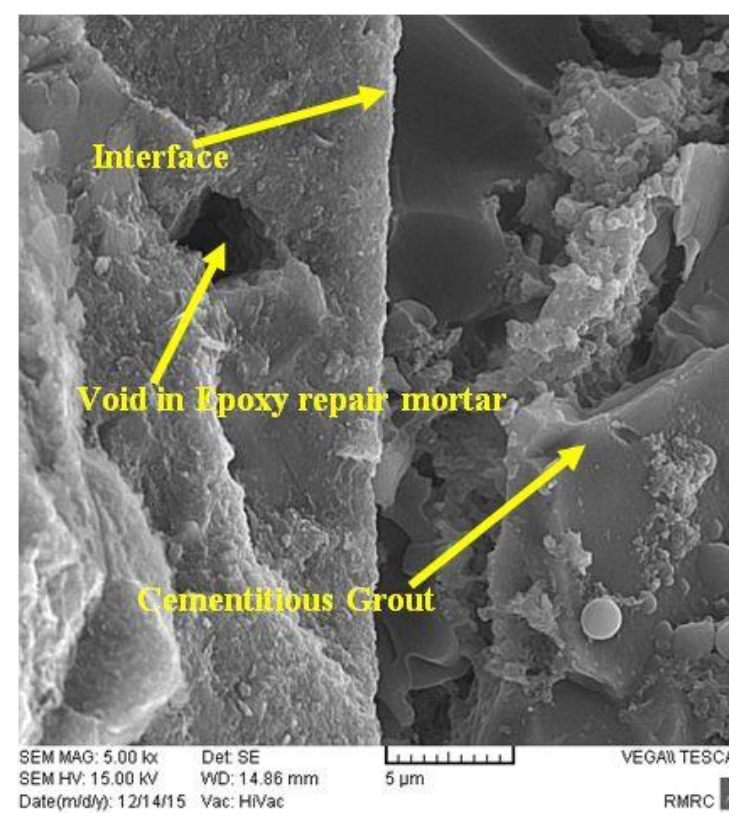

Figure 5. An Interface of Mortar and Repair Materials 
- An effective parameter for controlling quality of filling the gap is time limit that a wave needs to pass through mortar and crack. Time limit for a cracked mortar is more than the normal concrete. This means that recorded time for the repaired mortar is lower than a cracked one. Given the fact that the density of repairing materials is more than average density of concrete, the needed time for passing through a determined passage is lower than that of uncracked mortar. In the other case, if repairing material density is lower than concrete density, the recorded time will be more than the sound concrete.

- The wider the crack, the more it leads to increasing time factor. Since the pulse passes through a longer way in repairing a material which has lower density than cracked material or mortar, therefore the pulse passes through the cracked material for a longer time.

- Using denser repair materials can reduce time factor. Which means time pulse passing through repair material descends because of pulse velocity increase in areas with high density.

- By doing an extended research on Cementitious materials with different Cement content and aggregate size, a table can be designed which contains regular repair materials with a specific domain for width of crack that assigns a time factor for a certain concrete and cracks.

- Passage time of waves indirectly in all repaired samples was in average $25.61 \%$ more than a straight way; and this is called error in non-straight way.

- Presence of gap and not filling some parts due to bad injection or not bleeding the crack can cause errors in results. Therefore changing the position of sender and receivers probe on the surface of mortar, or concrete on a specific crack will show the above mentioned weak points. Therefore, these methods can be used for finding voids and gaps in Cementitious and repair materials.

\section{REFRENCES}

ACI Committee 224 "Causes, Evaluation, and Repair of Cracks in Concrete Structures"(224.1R-07). Farmington Hills (MI): American Concrete Institute; 2007.

ACI Committee 503. "Use of Epoxy Compounds with Concrete" (ACI 503R-93 (Reapproved 2008)). Farmington Hills (MI): American Concrete Institute; 1993.

ACI Committee 546. "Concrete Repair Guide" (546R-04)". Farmington Hills (MI): American Concrete Institute; 2004.

ASTM C597-97. "Standard Test Method for Pulse Velocity through Concrete". West Conshohocken (PA): ASTM International; 1997.

Dr V K RAINA (1994). "Concrete Bridges (Inspection, Repair, Strengthening, Testing and Load Capacity Evaluation)." New Delhi, Tata McGraw-Hill Publishing Company Limited.

IAEA-TCS-17 (2002). Printed by the LAEA in Austria. (2002). "Guide Book on Non-destructive Testing of Concrete Structures." Sept. 2002.

MYLES A. MURRA., (1987). "Epoxy Injection Welds Cracks Back Together." USA, the Aberdeen Group.

Norbert Delatte (2009). "Failure, Distress and Repair of Concrete Structures." UK. Woodhead publishing limited.

UNICEMNTO. (2004). "Testing Concrete - part4: Determination of Ultrasonic Pulse Velocity." UNI EN 12504-4, Aug. 2004. 